\title{
EFFECT OF PLANTING TIME AND CORMS TREATMENT WITH GIBBERELLIC ACID ON GROWTH, FLOWERING, AND VASE LIFE OF FREESIA HYBRIDA 'CORONA'
}

\author{
Short communication \\ Asmaa Mohammed ADIL*, Ebtisam Esmaael AHMED, Angham Talal AL-CHALABI, \\ Ali Farouq AL-MA'ATHEDI \\ Department of Horticulture and Landscape Gardening, College of Agriculture and Forestry, \\ University of Mosul, Mosul, Al-Majmoaa Street 41002, Iraq
}

Received: January 2021; Accepted: April 2021

\begin{abstract}
Freesia hybrida is one of the most important cut flowers with a short vase life. The present study was conducted to explain the effect of the two planting dates December 1st and 15th and soaking corms before planting in gibberellic acid at concentrations of 0,75 , and $150 \mathrm{mg} \cdot \mathrm{L}^{-1}$ on the growth, flowering, and flowers quality of Freesia hybrida 'Corona'. A larger diameter of the inflorescence stem and floret head, fresh weight of inflorescence, and longer vase life were obtained when planted on December 1st. Soaking the corms in a $\mathrm{GA}_{3}$ solution of $150 \mathrm{mg} \cdot \mathrm{L}^{-1}$ before planting significantly extended the vase life compared to the control. Finally, it can be concluded that the planting of corms soaked in a solution of $150 \mathrm{mg} \cdot \mathrm{L}^{-1} \mathrm{GA}_{3}$ on December 1 st in unheated greenhouses can improve the growth, development, and quality of flowers of Freesia hybrida 'Corona'.
\end{abstract}

Key words: cut flowers, corm yield, flower quality, days to sprouting, water uptake

\section{INTRODUCTION}

Freesia hybrida (Iridaceae) is a commonly produced ornamental plant that bears fragrant flowers with a short vase life (Zencirkiran 2002). It is used as cut flower and as a pot plant outside or indoor (Younis et al. 2012). The agro-climatic diversity in northern Iraq (Mediterranean) is suitable for growing freesia commercially in either open fields or under greenhouse; however, the number of commercially viable species for cut flowers is extremely limited in the local market. The date of planting is an important factor to regulate the growth and quality of freesia. However, the precise timing of flowering is predictable only under controlled conditions. Most of the studies under a natural condition in Iraq reported that the corm sprouts in early-late autumn (15/9 to $15 / 11)$ and the flowering in the greenhouse is expected about 14-17 weeks later, while in the field, it is expected after 17-23 weeks (AL-Sawaf \&
Alwan 2010; Jasim 2009). In north Iraq, the temperature rises quickly in the spring. This abrupt increase in temperature decreases the inflorescence stem length and quality of the spikes. Locally produced flowers have short spikes of low quality and low yield (AL-Sawaf \& Alwan 2010). Furthermore, the quality of flowers is affected negatively by rains at the end of winter and spring. There is no study on the possibility to change the sprouting date to the early winter, which is caused by troubles in import procedures. In the result, farmers are forced to plant imported bulbs at a later date in order to avoid losing the planting season and minimizing financial losses. On the other hand, freesia is prone to fungal diseases when planted in the autumn, and this result is referred by Le Nard (2002) who proposes to avoid tulip bulb infection with fusarium by delaying planting dates, which can be as late as December.

Growth regulators have many commercial applications in ornamental plants. Gibberellins are well-known and often used growth regulators. 
According to Żurawik and Placek (2013), treatment of freesia (Freesia Eckl. ex Klatt) corms with gibberellic acid at various concentrations $(10,20,40$, $80,160 \mathrm{mg} \cdot \mathrm{dm}^{-3}$ ) interrupts the dormancy of corms, accelerates plant flowering, and increases the length of the stem inflorescence. Gibberellic acid stimulates shoot elongation (Hanks 1984; Al-Ma'athedi et al. 2018), plant height, and a total number of leaves in freesia (Żurawik and Placek 2013) and in gladiolus (Padmalatha et al. 2014); it also stimulates the growth of shoots and leaves of Tulipa (Kumar et al. 2013), and Freesia $\times$ hybrida (Cocozza Talia 1985). Żurawik and Placek (2013) reported the influence of gibberellic acid on an increase in weight of corms of freesia. $\mathrm{GA}_{3}$ delays the senescence of gladiolus flowers by reducing the senescence-promoting effect of ethylene (Faraji et al. 2011). Our study was aimed at finding the optimal planting time for Freesia hybrida 'Corona' corms in the early winter period and assessing the soaking of the corms before planting in $\mathrm{GA}_{3}$ solutions in order to obtain cut flowers with a high market value.

\section{MATERIALS AND METHODS}

The pot experiment was carried out under unheated greenhouse conditions at the Landscape and Horticulture Department, Agriculture Forestry College, Mosul University, Iraq, during December 2017 to June 2018. Freesia hybrida 'Corona' corms with 5-6 $\mathrm{g}$ weight and 5-6 cm in circumference were grown individually in pots of $15 \mathrm{~cm}$ diameter, filled with a peat moss substrate "K ProLine TS 1 Fine Propagation (kla-10410)", produced by KlasmannDeilmann (Germany). NPK water-soluble fertilizer $\mathrm{PRO} \cdot \mathrm{SOL}^{\mathrm{TM}}$ (20-20-20), all-purpose fertilizer produced by PRO-SOL (USA), was added at $2 \mathrm{~g}$ per pot monthly.

The daytime temperature in the greenhouse in December was $16-21^{\circ} \mathrm{C}$, in January $14-18{ }^{\circ} \mathrm{C}$, in February $17-19{ }^{\circ} \mathrm{C}$, in March $19-25^{\circ} \mathrm{C}$, in April $24-30{ }^{\circ} \mathrm{C}$, and in May $30-36^{\circ} \mathrm{C}$. The average midnight temperatures for the months were 9.80, 3.95, 5.65, 9.05, 9.60, and $26.60^{\circ} \mathrm{C}$, respectively (Fig. 1).

\section{Factors and experimental design}

The experiment was arranged as a two factorial with randomized complete block design (RCBD) with three replications. Each experimental treatment consisted of 5 corms ( 5 pots), in each replication $(n=15)$. The corms of freesia were soaked in a solution of $\mathrm{GA}_{3}$ at 0,75 , and $150 \mathrm{mg} \cdot \mathrm{L}^{-1}$ for $60 \mathrm{~min}$. before planting (the first factor). After the treatment, corms were left to dry for 2 hours and then planted. The second factor was represented by two dates of planting, 1st and 15th December.

Plant growth, flowering, and corm yield parameters Three growth parameters were recorded: number of days to sprout, number of leaves (measured when the first floret colored), and plant height (measured from the soil surface to the top of floret head). Flowering parameters (taken at the beginning of flowering) included a number of days from planting to flowering (to the appearance of inflorescence stem), number of days to the first floret coloring, inflorescence stem length, inflorescence stem diameter, floret head diameter, florets number per inflorescence, and fresh weight of inflorescences. After the appearance of leaves yellowing, corms and cormels were removed, and corms were cleaned after drying. Corm yield parameters included the mother corm diameter, fresh weight of the mother corm, fresh weight of the cormels, and their number per mother corm.

\section{Water uptake and vase life measurement}

The water uptake and vase life were measured in the laboratory, at a temperature of $27 \pm 2{ }^{\circ} \mathrm{C}$ and humidity of $65 \pm 5 \%$. The inflorescence stems were excised in the morning at the stage of opening and coloring of the first buds (Zencirkiran 2002), transferred to the laboratory, recut to $30 \mathrm{~cm}$, and placed in separate vases containing $300 \mathrm{ml}$ distilled water that was changed every 3 days.

Solution uptake was measured every 3 days, and vase life was taken from the time of the first floret opening to the time when more than $50 \%$ of the florets were visibly senescing and petals wilted.

\section{Statistical analysis}

All plants were utilized for measuring all parameters, and then the results were analyzed statistically using the analysis of variance (ANOVA) procedure with SAS software (9.0) in the randomized complete block design. The values of the means were compared by Duncan's multiple range test at the significant level $\mathrm{p} \leq 0.05$. 


\section{RESULTS AND DISCUSSION}

\section{Number of days to sprouting, flowering, and first floret coloration}

All plants under experiment sprouted. The planting time had a significant effect on the time of sprouting (Table 1). The results showed a significant difference between corms planted on December 15th that needed only 20.9 days and on December 1 st that needed 31 days. A temperature of $18-22{ }^{\circ} \mathrm{C}$ is required for good germination, which in December is about $16-21{ }^{\circ} \mathrm{C}$ during daytime (Fig. 1), while $10{ }^{\circ} \mathrm{C}$ is adequate for slow growth, and $12-15^{\circ} \mathrm{C}$ is suitable for faster growth (Mansour 1968).

The later planting shortened the time to flower by 17 days but did not affect the time of the first florets' coloration. High temperatures delayed the process of flower initiation in freesia after planting in the temperature range of $9-15{ }^{\circ} \mathrm{C}$ (Berghoef et al. 1986). Also, the number of days to flower decreased with increasing greenhouse temperature, but the response varied somewhat among the cultivars; for example, Aurora cultivar flowered earlier at $15^{\circ} \mathrm{C}$ than at $20^{\circ} \mathrm{C}$ (Wulster et al. 1989). To delay flowering until May, Anderson (2006) planted corms from December 1st to December 20th.
These results are in concurrence to that of Aftab et al. (2007), which reported a decrease in the time to flower from 145-146 days to 134-137 days when delayed planting date from 15 th October to 30th October.

The $\mathrm{GA}_{3}$ application did not affect the time of sprouting (Table 1). $\mathrm{GA}_{3}$ corm-soaking did not influence the number of days to sprout but shortened the time to flower and delayed significantly flower coloration when was applied in higher concentrations. The sprouting time is connected with day and night temperature. Application of $\mathrm{GA}_{3}$ speeds flowering in gladiolus (Baskaran et al. 2017; Baskaran \& Abirami 2016). Speeding of freesia flowering with $\mathrm{GA}_{3}$ treatment was significant only at the later corm planting. Application of $\mathrm{GA}_{3}$ delayed also the first floret coloring. The results of Cocozza Talia (1985) showed that $\mathrm{GA}_{3}$ treatment in freesia induces advanced flowering without changing the qualitative characteristics of the flowers. The improving effect of $\mathrm{GA}_{3}$ on flowering characteristics may be due to their stimulatory effect on cell division, elongation, and differentiation. Earlier flowering of plants treated by $\mathrm{GA}_{3}$ might be due to their vital role in the production and regulation of floral stimulus (Taha 2012).

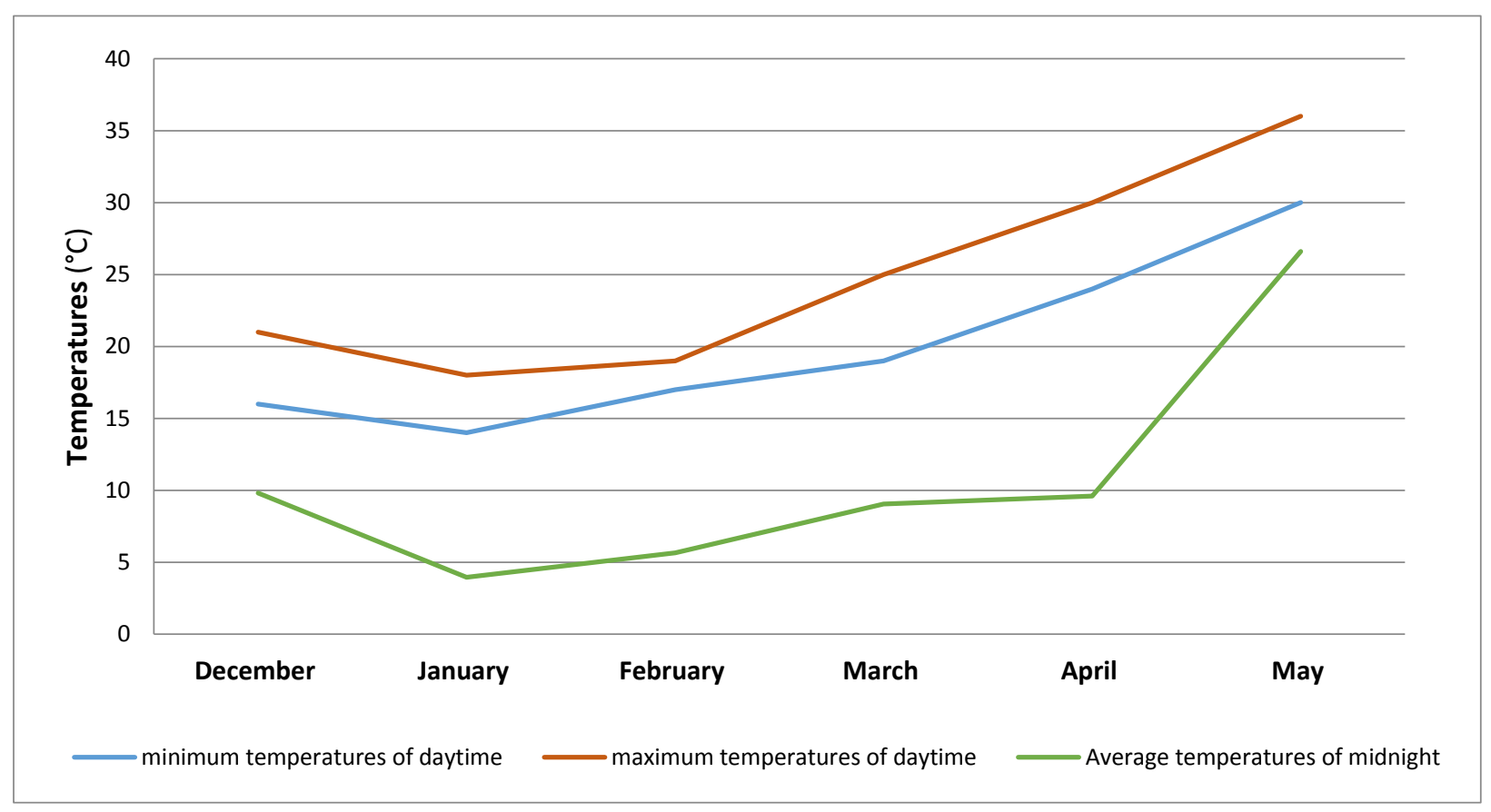

Fig. 1. The average temperatures in the greenhouse during the experiment 
Table 1. The effect of planting date and $\mathrm{GA}_{3}$ treatment on plant growth parameters of Freesia hybrida 'Corona'

\begin{tabular}{|c|c|c|c|c|c|c|}
\hline \multicolumn{2}{|c|}{ Treatment } & $\begin{array}{l}\text { No. } \\
\text { of days } \\
\text { to sprout }\end{array}$ & $\begin{array}{l}\text { No. } \\
\text { of days } \\
\text { to flower }\end{array}$ & $\begin{array}{l}\text { No. } \\
\text { of days to first } \\
\text { floret coloration }\end{array}$ & $\begin{array}{l}\text { Plant height } \\
\text { (cm) }\end{array}$ & $\begin{array}{c}\text { No. } \\
\text { of leaves }\end{array}$ \\
\hline \multirow{2}{*}{$\begin{array}{l}\text { Planting } \\
\text { date }\end{array}$} & $1^{\text {st }}$ Dec. & $31.0 \pm 3.7 \mathrm{~A}$ & $117.7 \pm 4.4 \mathrm{~A}$ & $127.3 \pm 3.3 \mathrm{~A}$ & $43.7 \pm 6.1 \mathrm{~A}$ & $8.8 \pm 0.5 \mathrm{~A}$ \\
\hline & $15^{\text {th }}$ Dec. & $20.9 \pm 2.5 \mathrm{~B}$ & $100.3 \pm 2.0 \mathrm{~B}$ & $109.4 \pm 2.1 \mathrm{~B}$ & $45.0 \pm 2.4 \mathrm{~A}$ & $7.2 \pm 0.4 \mathrm{~B}$ \\
\hline \multirow{3}{*}{$\begin{array}{c}\mathrm{GA}_{3} \\
\left(\mathrm{mg} \cdot \mathrm{L}^{-1}\right)\end{array}$} & 0 & $26.6 \pm 5.8 \mathrm{~A}$ & $111.1 \pm 11.9 \mathrm{~A}$ & $119.4 \pm 9.8 \mathrm{~A}$ & $42.0 \pm 3.5 \mathrm{~B}$ & $8.0 \pm 0.9 \mathrm{~A}$ \\
\hline & 75 & $26.5 \pm 5.5 \mathrm{~A}$ & $109.0 \pm 9.9 \mathrm{AB}$ & $117.8 \pm 10.8 \mathrm{~A}$ & $43.5 \pm 4.1 \mathrm{AB}$ & $8.0 \pm 0.8 \mathrm{~A}$ \\
\hline & 150 & $24.7 \pm 7.6 \mathrm{~A}$ & $106.8 \pm 7.5 \mathrm{~B}$ & $117.9 \pm 9.8 \mathrm{~A}$ & $47.5 \pm 4.7 \mathrm{~A}$ & $8.0 \pm 1.1 \mathrm{~A}$ \\
\hline \multicolumn{7}{|c|}{ Planting date $\times \mathrm{GA}_{3}$} \\
\hline \multirow{3}{*}{$1^{\text {st }}$ Dec. } & 0 & $31.0 \pm 4.7 \mathrm{a}$ & $121.3 \pm 5.3 \mathrm{a}$ & $127.9 \pm 4.6 \mathrm{a}$ & $40.0 \pm 4.3 \mathrm{~b}$ & $8.8 \pm 0.3 \mathrm{a}$ \\
\hline & 75 & $31.3 \pm 1.4 \mathrm{a}$ & $118.1 \pm 1.1 \mathrm{ab}$ & $127.5 \pm 2.3 \mathrm{a}$ & $42.3 \pm 4.5 \mathrm{ab}$ & $8.6 \pm 0.6 \mathrm{a}$ \\
\hline & 150 & $30.6 \pm 5.7 \mathrm{a}$ & $113.6 \pm 1.6 \mathrm{~b}$ & $126.4 \pm 3.9 \mathrm{a}$ & $48.6 \pm 7.2 \mathrm{a}$ & $8.9 \pm 0.6 \mathrm{a}$ \\
\hline \multirow{3}{*}{$15^{\text {th }}$ Dec. } & 0 & $22.2 \pm 2.0 \mathrm{~b}$ & $100.8 \pm 3.6 \mathrm{c}$ & $110.9 \pm 1.6 \mathrm{~b}$ & $44.0 \pm 1.0 \mathrm{ab}$ & $7.2 \pm 0.1 \mathrm{~b}$ \\
\hline & 75 & $21.6 \pm 1.9 \mathrm{~b}$ & $100.0 \pm 1.1 \mathrm{c}$ & $108.0 \pm 1.7 \mathrm{~b}$ & $44.7 \pm 4.3 \mathrm{ab}$ & $7.3 \pm 0.5 b$ \\
\hline & 150 & $18.9 \pm 2.9 \mathrm{~b}$ & $99.9 \pm 0.8 \mathrm{c}$ & $109.3 \pm 2.5 \mathrm{~b}$ & $46.3 \pm 1.0 \mathrm{ab}$ & $7.1 \pm 0.7 \mathrm{~b}$ \\
\hline
\end{tabular}

Means that have same letters in each column are nonsignificant statistically at $p=0.05$ (DMR test); values are means \pm standard deviation; capital letters refer to main effects, while lower case letters refer to interactions

\section{Plant height and number of leaves}

The time of planting did not influence plant height contrary to the $\mathrm{GA}_{3}$ (Table 1). Plants, which corms were soaked in the $\mathrm{GA}_{3}$ solution $150 \mathrm{mg} \cdot \mathrm{L}^{-1}$, were $13.1 \%$ longer over the non-soaked control. The promotion of plant height with $\mathrm{GA}_{3}$ in freesia was earlier reported by Żurawik and Placek (2013). This treatment was more effective (higher by $21.5 \%$ ) at earlier planting. The main function of $\mathrm{GA}_{3}$ is cell elongation and division, and it is known to be involved in various processes of plant development. In various plants, exogenous gibberellin promotes shoot elongation and plant height. This was confirmed in gladiolus (Padmalatha et al. 2014; Chopde et al. 2015; Baskaran et al. 2017; Baskaran \& Abirami 2016), Iris (Al-Khassawneh et al. 2006), and Tuberose (Asil et al. 2011).

Contrary to plant height, the leaf number was regulated by the time of planting but not by $\mathrm{GA}_{3}$ application (Table 1). This finding confirmed the results of Thompson et al. (2011) as they reported the higher number of leaves in Watsonia (Iridaceae) in plants growing under long-day and higher temperatures. Thus, it is desirable to grow freesia at 12 $15^{\circ} \mathrm{C}$ for obtaining $6-8$ leaves prior to flowering, which is required for breaking dormancy of the corms and optimal quality and yield of freesia flowers (Dole 2003).

\section{Quality of flowers}

The result showed that later corm planting and soaking in $\mathrm{GA}_{3}$ affected inflorescence lengthening (Table 2). Stem diameter was larger in plants in which corms were planted earlier and $\mathrm{GA}_{3}$ did not affect this trait. These results are inconsistent with the results of Aftab et al. (2007), who reported that the freesia inflorescence length decreased with the planting delayed from 15 th to 30 th October. $\mathrm{GA}_{3}$ increases inflorescence stem length through cell enlargement and cell division (Hartmann et al. 1990; Daykin et al. 1997; Kumar et al. 2013), which might have elongate the stalk length. Several workers have already reported an increase in the length of the stalk in Iris (Al-Khassawneh et al. 2006), in Tuberose (Asil et al. 2011; Shanker et al. 2011), and in Gladiolus (Baskaran et al. 2017; Baskaran \& Abirami 2016; Sajjad et al. 2014) due to $\mathrm{GA}_{3}$ treatment. Larger stem and floret head diameter and fresh weight of inflorescence were correlated with leaf number that provides more metabolites that can strengthen the plant. 
Table 2. The effect of planting date and $\mathrm{GA}_{3}$ treatment on flowering parameters of Freesia hybrida 'Corona'

\begin{tabular}{|c|c|c|c|c|c|c|c|c|}
\hline \multicolumn{2}{|c|}{ Treatment } & $\begin{array}{l}\text { Inflo- } \\
\text { rescence } \\
\text { stem } \\
\text { length } \\
(\mathrm{cm})\end{array}$ & $\begin{array}{c}\text { Inflorescence } \\
\text { stem } \\
\text { diameter } \\
(\mathrm{mm})\end{array}$ & $\begin{array}{l}\text { Floret head } \\
\text { diameter } \\
(\mathrm{cm})\end{array}$ & $\begin{array}{l}\text { No. } \\
\text { of florets } \\
\text { per inflo- } \\
\text { rescence }\end{array}$ & $\begin{array}{c}\text { Fresh weight } \\
\text { of inflo- } \\
\text { rescence } \\
(\mathrm{g})\end{array}$ & $\begin{array}{l}\text { Water uptake } \\
(\mathrm{ml})\end{array}$ & $\begin{array}{l}\text { Vase life } \\
\text { (days) }\end{array}$ \\
\hline \multirow{2}{*}{$\begin{array}{l}\text { Planting } \\
\text { date }\end{array}$} & $1^{\text {st }}$ Dec. & $34.7 \pm 6.9 \mathrm{~B}$ & $3.6 \pm 0.2 \mathrm{~A}$ & $4.6 \pm 0.3 \mathrm{~A}$ & $6.8 \pm 0.5 \mathrm{~A}$ & $7.9 \pm 1.0 \mathrm{~A}$ & $6.3 \pm 0.7 \mathrm{~A}$ & $6.8 \pm 1.5 \mathrm{~A}$ \\
\hline & $15^{\text {th }}$ Dec. & $38.9 \pm 2.6 \mathrm{~A}$ & $3.0 \pm 0.2 \mathrm{~B}$ & $4.1 \pm 0.2 \mathrm{~B}$ & $6.9 \pm 0.4 \mathrm{~A}$ & $6.0 \pm 0.2 \mathrm{~B}$ & $6.6 \pm 2.4 \mathrm{~A}$ & $5.3 \pm 1.6 \mathrm{~B}$ \\
\hline \multirow{3}{*}{$\begin{array}{c}\mathrm{GA}_{3} \\
\left(\mathrm{mg} \cdot \mathrm{L}^{-1}\right)\end{array}$} & 0 & $32.9 \pm 5.2 \mathrm{~B}$ & $3.3 \pm 0.5 \mathrm{~A}$ & $4.1 \pm 0.1 \mathrm{~B}$ & $6.5 \pm 0.3 \mathrm{~B}$ & $6.5 \pm 0.9 \mathrm{~B}$ & $5.1 \pm 1.2 \mathrm{~B}$ & $5.0 \pm 2.0 \mathrm{~B}$ \\
\hline & 75 & $36.2 \pm 5.2 \mathrm{~B}$ & $3.3 \pm 0.3 \mathrm{~A}$ & $4.4 \pm 0.2 \mathrm{~A}$ & $6.7 \pm 0.2 \mathrm{AB}$ & $6.7 \pm 0.8 \mathrm{~B}$ & $6.8 \pm 1.6 \mathrm{~A}$ & $6.0 \pm 1.6 \mathrm{AB}$ \\
\hline & 150 & $41.4 \pm 1.7 \mathrm{~A}$ & $3.4 \pm 0.4 \mathrm{~A}$ & $4.6 \pm 0.4 \mathrm{~A}$ & $7.2 \pm 0.5 \mathrm{~A}$ & $7.7 \pm 1.6 \mathrm{~A}$ & $7.6 \pm 1.4 \mathrm{~A}$ & $7.2 \pm 0.7 \mathrm{~A}$ \\
\hline \multicolumn{9}{|c|}{$\underline{\text { Planting date } \times \mathrm{GA}_{3}}$} \\
\hline \multirow{3}{*}{$1^{\text {st }}$ Dec. } & 0 & $28.6 \pm 4.2 \mathrm{c}$ & $3.6 \pm 0.4 \mathrm{a}$ & $4.2 \pm 0.1 \mathrm{bc}$ & $6.4 \pm 0.5 \mathrm{~b}$ & $7.3 \pm 0.4 \mathrm{~b}$ & $6.1 \pm 0.6 \mathrm{~b}$ & $6.0 \pm 2.0 \mathrm{ab}$ \\
\hline & 75 & $33.3 \pm 5.2 \mathrm{bc}$ & $3.6 \pm 0.1 \mathrm{a}$ & $4.6 \pm 0.2 \mathrm{ab}$ & $6.6 \pm 0.1 \mathrm{ab}$ & $7.4 \pm 0.3 \mathrm{~b}$ & $6.3 \pm 0.5 \mathrm{~b}$ & $7.0 \pm 2.0 \mathrm{a}$ \\
\hline & 150 & $42.3 \pm 0.8 \mathrm{a}$ & $3.7 \pm 0.2 \mathrm{a}$ & $5.0 \pm 0.1 \mathrm{a}$ & $7.4 \pm 0.4 \mathrm{a}$ & $8.9 \pm 1.2 \mathrm{a}$ & $6.6 \pm 1.2 \mathrm{ab}$ & $7.3 \pm 0.5 \mathrm{a}$ \\
\hline \multirow{3}{*}{$15^{\text {th }}$ Dec. } & 0 & $37.2 \pm 1.5 \mathrm{ab}$ & $2.9 \pm 0.3 \mathrm{~b}$ & $4.0 \pm 0.1 \mathrm{c}$ & $6.5 \pm 0.2 \mathrm{~b}$ & $5.7 \pm 0.3 \mathrm{c}$ & $4.1 \pm 0.8 \mathrm{~b}$ & $4.0 \pm 1.7 \mathrm{~b}$ \\
\hline & 75 & $39.2 \pm 3.7 \mathrm{ab}$ & $3.0 \pm 0.3 \mathrm{~b}$ & $4.2 \pm 0.2 \mathrm{bc}$ & $6.8 \pm 0.3 \mathrm{ab}$ & $6.0 \pm 0.2 \mathrm{c}$ & $7.2 \pm 2.3 \mathrm{ab}$ & $5.0 \pm 0.0 \mathrm{ab}$ \\
\hline & 150 & $40.5 \pm 2.0 \mathrm{a}$ & $3.0 \pm 0.2 \mathrm{~b}$ & $4.2 \pm 0.3 \mathrm{bc}$ & $6.9 \pm 0.6 \mathrm{ab}$ & $6.3 \pm 0.5 \mathrm{c}$ & $8.6 \pm 0.9 \mathrm{a}$ & $7.0 \pm 1.0 \mathrm{a}$ \\
\hline
\end{tabular}

Means that have same letters in each column are nonsignificant statistically at $\mathrm{p}=0.05$ (DMR test); values are means \pm standard deviation; capital letters refer to main effects, while lower case letters refer to interactions

Floret's head diameter was influenced by both studied factors. Different planting dates and various concentrations of $\mathrm{GA}_{3}$ and interaction of these factors had a significant effect on floret head diameter. The diameter of the flower head and fresh weight of inflorescence were greater in plants treated with $\mathrm{GA}_{3}$ (Table 2). The opposite results were obtained by Żurawik and Placek (2013), working with Easy Pot Freesias, and confirmed results of Kumar and Misra (2012) on tulip.

The number of florets per inflorescence did not depend on the time of corms planting but was higher in plants that corms were soaked in 150 $\mathrm{mg} \cdot \mathrm{L}^{-1} \mathrm{GA}_{3}$ (Table 2). The least number of florets, 6.5 per spike, was noticed in control plants. According to Żurawik and Placek (2013), treating Easy Pot Freesia with gibberellic acid increases the number of flowers depended on the concentration of the gibberellic acid. The obtained results are in line with those of Pogroszewska et al. (2007) on Allium, Kumar and Misra (2012) on tulip, Baskaran et al. (2017) and Baskaran and Abirami (2016) on Gladiolus.

\section{Vase life}

There were no significant differences in water uptake due to $\mathrm{GA}_{3}$ application to corms (Table 2). The amount of water uptake increased by increasing $\mathrm{GA}_{3}$ concentration. The interaction of planting date $\times \mathrm{GA}_{3}$ was significant. The best option was planting the corms on December 15th coupled with $\mathrm{GA}_{3}$ at $150 \mathrm{mg} \cdot \mathrm{L}^{-1}$, which caused a maximum solution uptake of $8.6 \mathrm{ml}$.

It is worth noting that the maximum vase life was 6.8 days that was recorded for the corms planted on December 1st, compared to 5.3 days for the flowers obtained from corms planted on December 15th. The results in Table 2 show that treatment of $\mathrm{GA}_{3}$ significantly extended the vase life of freesia cut flowers compared to control. The longest vase life, 7.3 days, was obtained by planting corms on December $1 \mathrm{st}$ and using $150 \mathrm{mg} \cdot \mathrm{L}^{-1} \mathrm{GA}_{3}$; while, the vase life of flowers from untreated corms was only 5 days. This result is in line with Ramzan et al. (2014) and Kumar et al. (2013) who found longer vase life of tulip obtained on plants treated with $400 \mathrm{mg} \cdot \mathrm{L}^{-1}$ gibberellic acids compared with the control plants. 
This result could be due to the role of gibberellin in controlling the transferring of nutrients from the leaves toward the flowers (Ahmed et al. 2016).

\section{Corm yield parameters}

The planting dates did not affect the corm yield parameters except the fresh weight of cormels (Table 3). Delay of planting decreased the fresh weight of cormels by $30 \%$. Soaking of cormels in $\mathrm{GA}_{3}$, especially at $150 \mathrm{mg} \cdot \mathrm{L}^{-1}$, caused an increase in mother corm weight and diameter. Similar findings concerning the increase in bulb diameter were reported for gladiolus. The increase of weight of corms with the application of $\mathrm{GA}_{3}$ can be attributed to its ability to increase the yield of photosynthetic products, which was reported in freesia by Żurawik and Placek (2013) and in gladiolus by Arora et al. (1992), Siraj and Al-Safar (2006), and Kumar and Misra (2012).

From the results of our investigation, it should be concluded that the choice of planting time of corms between 1st and 15th December could have significant consequences for freesia production. To the positives of earlier planting, anyone can account for more leaves, greater inflorescence and floret head diameter, greater fresh weight of inflorescence and cormels, and longer vase life. On the other hand, plants need more time for sprouting and flowering and produced shorter inflorescences. Flowers are produced almost at the same time as from corms planted two weeks later but inflorescences are stronger what influenced positively vase life. It has been suggested that an appropriate planting date can lower production costs by reducing the production period from 14-17 weeks to 12-13 weeks (ALSawaf \& Alwan 2010; Jasim 2009) and enable the production of flowers of higher quality and greater market value by offering products on the local market in early February and mid-March, when the supply of blooming flowers is low.

On the basis of the presented results, it can be concluded that soaking corms in $150 \mathrm{mg} \cdot \mathrm{L}^{-1} \mathrm{GA}_{3}$ had a positive effect on increasing the plant height, and it also caused the earliest stalking with a higher quality of flowers, increasing such parameters as the inflorescence stem length, floral head diameter, florets number per inflorescence, fresh weight of inflorescence, longer vase life, as well as greater corm diameter and weight. Therefore, we recommend the planting of Freesia hybrida 'Corona' corms soaked in $150 \mathrm{mg} \cdot \mathrm{L}^{-1} \mathrm{GA}_{3}$ on December $1 \mathrm{st}$ in unheated greenhouses.

Table 3. The effect of planting date and $\mathrm{GA}_{3}$ treatment on corm yield parameters of Freesia hybrida 'Corona'

\begin{tabular}{|c|c|c|c|c|c|}
\hline \multicolumn{2}{|c|}{ Treatment } & $\begin{array}{l}\text { Mother corm } \\
\text { diameter } \\
(\mathrm{mm})\end{array}$ & $\begin{array}{l}\text { Fresh weight } \\
\text { of mother corm } \\
(\mathrm{g})\end{array}$ & $\begin{array}{l}\text { Fresh weight } \\
\text { of cormels } \\
(\mathrm{g})\end{array}$ & $\begin{array}{c}\text { No. } \\
\text { of cormels } \\
\text { per mother corm }\end{array}$ \\
\hline \multirow{2}{*}{ Planting date } & $1^{\text {st }}$ Dec. & $22.2 \pm 2.1 \mathrm{~A}$ & $7.1 \pm 1.2 \mathrm{~A}$ & $3.4 \pm 0.7 \mathrm{~A}$ & $1.7 \pm 0.5 \mathrm{~A}$ \\
\hline & $15^{\text {th }}$ Dec. & $22.5 \pm 2.9 \mathrm{~A}$ & $7.5 \pm 0.8 \mathrm{~A}$ & $2.4 \pm 0.6 \mathrm{~B}$ & $1.8 \pm 0.9 \mathrm{~A}$ \\
\hline \multirow{3}{*}{$\begin{array}{c}\mathrm{GA}_{3} \\
\left(\mathrm{mg} \cdot \mathrm{L}^{-1}\right)\end{array}$} & 0 & $20.7 \pm 2.0 \mathrm{~B}$ & $6.5 \pm 1.1 \mathrm{~B}$ & $3.2 \pm 1.0 \mathrm{~A}$ & $2.0 \pm 1.1 \mathrm{~A}$ \\
\hline & 75 & $22.5 \pm 2.9 \mathrm{AB}$ & $7.4 \pm 0.7 \mathrm{AB}$ & $3.0 \pm 1.0 \mathrm{~A}$ & $2.0 \pm 0.4 \mathrm{~A}$ \\
\hline & 150 & $23.9 \pm 1.4 \mathrm{~A}$ & $8.1 \pm 0.7 \mathrm{~A}$ & $2.6 \pm 0.6 \mathrm{~A}$ & $1.3 \pm 0.5 \mathrm{~A}$ \\
\hline \multicolumn{6}{|c|}{ Planting date $\times \mathrm{GA}_{3}$} \\
\hline \multirow{3}{*}{$1^{\text {st }}$ Dec. } & 0 & $21.0 \pm 2.1 \mathrm{a}$ & $6.7 \pm 1.2 \mathrm{~b}$ & $3.8 \pm 0.7 \mathrm{a}$ & $1.4 \pm 0.3 \mathrm{a}$ \\
\hline & 75 & $21.5 \pm 1.1 \mathrm{a}$ & $7.2 \pm 1.0 \mathrm{ab}$ & $3.7 \pm 0.9 \mathrm{a}$ & $2.4 \pm 0.1 \mathrm{a}$ \\
\hline & 150 & $24.2 \pm 1.8 \mathrm{a}$ & $8.6 \pm 0.7 \mathrm{a}$ & $2.9 \pm 0.5 \mathrm{a}$ & $1.4 \pm 0.4 \mathrm{a}$ \\
\hline \multirow{3}{*}{$15^{\text {th }}$ Dec. } & 0 & $20.3 \pm 2.4 \mathrm{a}$ & $6.4 \pm 1.2 \mathrm{~b}$ & $2.7 \pm 1.0 \mathrm{a}$ & $2.6 \pm 1.3 \mathrm{a}$ \\
\hline & 75 & $23.5 \pm 4.2 \mathrm{a}$ & $7.5 \pm 0.4 \mathrm{ab}$ & $2.2 \pm 0.1 \mathrm{a}$ & $1.6 \pm 0.3 \mathrm{a}$ \\
\hline & 150 & $23.6 \pm 1.2 \mathrm{a}$ & $7.5 \pm 0.1 \mathrm{ab}$ & $2.4 \pm 0.7 \mathrm{a}$ & $1.2 \pm 0.6 \mathrm{a}$ \\
\hline
\end{tabular}

Means that have same letters in each column are nonsignificant statistically at $\mathrm{p}=0.05$ (DMR test); values are means \pm standard deviation; capital letters refer to main effects, while lower case letters refer to interactions 


\section{Acknowledgments}

The authors are very grateful to the University of Mosul, College of Agriculture and Forestry, Department of Horticulture and Landscape Gardening for their facilities, which helped to improve the quality of this work.

\section{Authorship contribution statement}

E.E.A., A.T.A., and A.M.A. performed the measurements; A.F.A. and A.M.A. were involved in planning and supervised the work; and A.F.A. and A.M.A. processed the experimental data, performed the analysis, drafted the manuscript, and designed the tables and figures. A.F.A. performed the calculations. A.F.A. aided in interpreting the results and worked on the manuscript. All authors discussed the results and commented on the manuscript.

\section{REFERENCES}

Aftab M., Shabbir G., Mahmood A. 2007. Production of high quality bulbous flowers in Pothwar. Proceedings of the International Symposium on Prospects of Horticultural Industry in Pakistan, University of Agriculture, Faisalabad, 28-30 March, pp. 315-321.

Ahmed T.S., Al-Maathedi A.F., Zahwan T.A. 2016. Improved productivity, quality in flowering of carnation Dianthus caryophyllus L. by growth regulators and liquor extract. Euphrates Journal of Agriculture Science 8: 38-43. [in Arabic with English abstract]

Al-Khassawneh N.M., Karam N.S., Shibli R.A. 2006. Growth and flowering of black iris (Iris nigricans Dinsm.) following treatment with plant growth regulators. Scientia Horticulturae 107: 187-193. DOI: 10.1016/j.scienta.2005.10.003.

Al-Ma'athedi A.F., Abbas A.J., Al-abdaly H.M. 2018. Effect of growth regulators on improving productivity and quality of carnation (Dianthus caryophyllus L.) flowers with economic study. Annals of Agricultural Sciences 63: 109-114. DOI: 10.1016/j.aoas.2018.04.005.

AL-Sawaf M.D., Alwan N.E. 2010. Effect of some agricultural treatment on the growth, flowering and yield of Freesia hybrida L. cv. Corona and Prominence. Mesopotamia Journal of Agriculture 38: 73 78. DOI: $10.33899 /$ magrj.2010.34176. [in Arabic with English abstract]

Anderson N.O. 2006. Flower breeding and genetics: Issues, challenges and opportunities for the 21 st century. Springer, pp. 665-673. DOI: 10.1007/978-14020-4428-1.
Arora J.S., Singh K., Grewal N.S. 1992. Effect of GA3 on cormel growth in gladiolus. Indian Journal of Plant Physiology 35: 202-206.

Asil M.H., Roein Z., Abbasi J. 2011. Response of tuberose (Polianthes tuberose L.) to gibberellic acid and benzyladenine. Horticulture, Environment, and Biotechnology 52: 46-51. DOI: 10.1007/s13580-011-0073-0.

Baskaran V., Abirami K. 2016. Effect of growth substances on growth, flowering and corm production in gladiolus (Gladiolus grandiflorus) cv White Prosperity under Bay Island conditions. Indian Journal of Agricultural Sciences 86: 216-219.

Baskaran V., Abirami K., Simhachalam P. 2017. Effect of growth regulating chemicals on flowering, corm production and post harvest life of gladiolus (Gladiolus grandiflorus) cv. Punjab Dawn in Bay Islands. Indian Journal of Agricultural Sciences 87: 551-554.

Berghoef J., Melcherts J.W.F., Mourits J.A.M., Zevenbergen A.P. 1986. Effect of temperature on initiation and development of freesia flowers. Acta Horticulturae 177: 636-636. DOI: 10.17660/actahortic.1986.177.110.

Chopde N., Patil A., Bhande M.H. 2015. Growth, yield and quality of gladiolus as influenced by growth regulators and methods of application. Plant Archives 15: 691-694.

Cocozza Talia M. 1985. Further research about the effects of gibberellic acid upon freesia flowering. Acta Horticulturae 167: 187-192. DOI: 10.17660/actahortic.1985.167.19.

Daykin A., Scott I.M., Causton D.R., Francis D. 1997. Gibberellin does not accelerate rates of cell division in the dwarf pea shoot apical meristem. Journal of Experimental Botany 48: 1147-1150. DOI: 10.1093/jxb/48.5.1147.

Dole J.M. 2003. Research approaches for determining cold requirements for forcing and flowering of geophytes. HortScience 38: 341-346. DOI: 10.21273/hortsci.38.3.341.

Faraji S., Naderi R., Ibadli O.V., Basaki T., Gasimov S.N., Hosseinova S. 2011. Effects of post harvesting on biochemical changes in Gladiolus cut flowers cultivars [White prosperity]. Middle-East Journal of Scientific Research 9: 572-577.

Hanks G.R. 1984. Factors affecting the response of tulips to gibberellin. Scientia Horticulturae 23: 379-390. DOI: 10.1016/0304-4238(84)90035-9. 
Hartmann H.T., Kester D.E., Davies Jr. F.T. 1990. Plant propagation: principles and practices, fifth edition. Prentice Hall, Englewood Cliffs, USA, pp. 647.

Jasim S.N. 2009. Effect of spraying with yeast suspension on vegetative, floral growth characters and vase life of freesia. Iraqi Journal of Agricultural Science 40: 110-119. [in Arabic with English abstract]

Kumar P.N., Misra R.L. 2012. Effect of plant growth regulators on growth, flowering and corm production of gladiolus cv. Snow Princess. Indian Journal of Agricultural Sciences 82(7): 632-637.

Kumar R., Ahmed N., Singh D.B., Sharma O.C., Lal S., Salmani M.M. 2013. Enhancing blooming period and propagation coefficient of tulip (Tulipa gesneriana L.) using growth regulators. African Journal of Biotechnology 12: 168-174. DOI: 10.5897/ajb12.2713.

Le Nard M. 2002. Effects of bulb planting date on growth of tulip 'Don Quichotte' under mild winter conditions. Acta Horticulturae 570: 153-156. DOI: 10.17660/actahortic.2002.570.17.

Mansour B.M.M. 1968. Effects of temperature and light on growth, flowering and corm formation in Freesia. Communications Agricultural University, Wageningen, the Netherlands, 76 p. https://edepot.wur.nl/285363

Padmalatha T., Satyanarayana Reddy G., Chandrasekhar R., Siva Shankar A., Chaturvedi A. 2014. Effect of pre planting treatment of corms with chemicals and plant growth regulators on vegetative growth, flowering and post harvest life in gladiolus. Indian Journal of Agricultural Research 48: 301-306. DOI: 10.5958/0976-058x.2014.00664.7.

Pogroszewska E., Laskowska H., Durlak W. 2007. The effect of gibberellic acid and benzyladenine on the yield of (Allium karataviense Regel.) 'Ivory Queen'. Acta Scientiarum Polonorum, Hortorum Cultus 6: 15-19.

Ramzan F., Younis A., Riaz A., Ali S., Siddique M.I., Lim K.B. 2014. Pre-planting exogenous application of gibberellic acid influences sprouting, vegetative growth, flowering, and subsequent bulb characteristics of 'Ad-Rem' tulip. Horticulture, Environment, and Biotechnology 55: 479-488. DOI: 10.1007/s13580-014-0113-7.
Sajjad Y., Jaskani M.J., Ashraf M.Y., Qasim M., Ahmad R. 2014. Response of morphological and physiological growth attributes to foliar application of plant growth regulators in gladiolus 'White Prosperity'. Pakistan Journal of Agricultural Sciences 51: 123-129.

Shanker K., Singh A.K., Singh H.K. 2011. Effect of plant growth regulators on spike yield and bulb production of tuberose (Polianthes tuberosa Linn.) Double. Plant Archives 11: 169-171.

Siraj Y.S., Al-Safar M.S. 2006. Effect of $\mathrm{GA}_{3}$ treatment and nitrogen on growth and development of gladiolus corms. Pakistan Journal of Biological Sciences 9: 2516-2519. DOI: 10.3923/pjbs.2006.2516.2519.

Taha R.A. 2012. Effect of some growth regulators on growth, flowering, bulb productivity and chemical composition of iris plants. Journal of Horticultural Science and Ornamental Plants 4: 215-220. DOI: 10.5829/idosi.jhsop.2012.4.2.249.

Thompson D.I., Mtshali N.P., Ascough G.D., Erwin J.E., Van Staden J. 2011. Flowering control in Watsonia: Effects of corm size, temperature, photoperiod and irradiance. Scientia Horticulturae 129: 493-502. DOI: 10.1016/j.scienta.2011.04.004.

Wulster G.J., Cartwright S., Gianfagna T.J. 1989. The effects of greenhouse temperature and ancymidol concentration on height and flowering time of Freesia hybrida grown as a container plant. Acta Horticulturae 252: 97-103. DOI: 10.17660/actahortic.1989.252.12.

Younis A., Bhatti M.Z.M., Riaz A., Tariq U., Arfan M., Nadeem M., Ahsan M. 2012. Effect of different types of mulching on growth and flowering of Freesia alba cv. Aurora. Pakistan Journal of Agricultural Sciences 49: 429-433.

Zencirkiran M. 2002. Cold storage of Freesia refracta 'Cordula'. New Zealand Journal of Crop and Horticultural Science 30: 171-174. DOI: 10.1080/01140671.2002.9514212.

Żurawik P., Placek M. 2013. The influence of selected growth regulators on development, decorative value and yield of corms of Easy Pot Freesia (Freesia Eckl. ex Klatt). Part I. Gibberellin $\mathrm{A}_{3}$. Acta Scientiarum Polonorum, Hortorum Cultus 12: 55-64. 